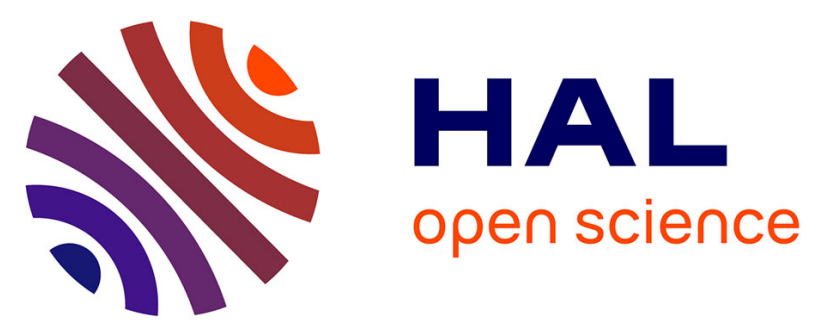

\title{
Enhanced mercury deposition by Amazonian orographic precipitation: Evidence from high-elevation Holocene records of the Lake Titicaca region (Bolivia)
}

\author{
Stéphane Guédron, Marie-Pierre Ledru, Katarina Escobar-Torrez, A.L.
} Develle, Elodie Brisset

\section{To cite this version:}

Stéphane Guédron, Marie-Pierre Ledru, Katarina Escobar-Torrez, A.L. Develle, Elodie Brisset. Enhanced mercury deposition by Amazonian orographic precipitation: Evidence from high-elevation Holocene records of the Lake Titicaca region (Bolivia). Palaeogeography, Palaeoclimatology, Palaeoecology, 2018, 551, pp.577-587. 10.1016/j.palaeo.2018.09.023 . hal-02555406

\author{
HAL Id: hal-02555406 \\ https://hal.science/hal-02555406
}

Submitted on 27 Apr 2020

HAL is a multi-disciplinary open access archive for the deposit and dissemination of scientific research documents, whether they are published or not. The documents may come from teaching and research institutions in France or abroad, or from public or private research centers.
L'archive ouverte pluridisciplinaire HAL, est destinée au dépôt et à la diffusion de documents scientifiques de niveau recherche, publiés ou non, émanant des établissements d'enseignement et de recherche français ou étrangers, des laboratoires publics ou privés. 


\title{
Enhanced mercury deposition by Amazonian orographic precipitation: Evidence from high-elevation Holocene records of the Lake Titicaca region (Bolivia)
}

\author{
S. Guédron ${ }^{\mathrm{a}, \mathrm{b}, *}$, M.-P. Ledru ${ }^{\mathrm{c}}$, K. Escobar-Torrez ${ }^{\mathrm{d}}$, A.L. Develle ${ }^{\mathrm{e}}$, E. Brisset ${ }^{\mathrm{a}, \mathrm{f}, \mathrm{g}}$ \\ ${ }^{\mathrm{a}}$ Univ. Grenoble Alpes, Univ. Savoie Mont Blanc, CNRS, IRD, IFSTTAR, ISTerre, 38000 Grenoble, France \\ ${ }^{\mathrm{b}}$ Laboratorio de Hidroquímica, Instituto de Investigaciones Químicas, Universidad Mayor de San Andres, Campus Universitario de Cota Cota, casilla 3161 La Paz, Bolivia \\ ${ }^{\mathrm{c}}$ Institut des Sciences de l'Evolution de Montpellier (ISEM), University of Montpellier IRD CNRS EPHE, 34095 Montpellier, France \\ ${ }^{\mathrm{d}}$ Herbario Nacional de Bolivia, UMSA, La Paz, Bolivia \\ environnement, Dynamique et Territoires de Montagne (EDYTEM), Université Savoie Mont Blanc, CNRS, 73373 Le Bourget du Lac, France \\ ${ }^{\mathrm{f}}$ IPHES, Zona Educacional 4, Campus Sescelades URV, Edifici W3, Tarragona, Spain \\ ${ }^{\mathrm{g}}$ Àrea de Prehistòria, Universitat Rovira i Virgili (URV), Avinguda de Catalunya 35, Tarragona, Spain
}

\section{Keywords:}

Central Andes

Peat sediment

Pollen, stable isotopes

Climate change

Atlantic Meridional Overturning Circulation

\begin{abstract}
A B S T R A C T
Very few studies have focused on historical mercury $(\mathrm{Hg})$ deposition in the Southern Hemisphere, especially for the pre-mining period. Therefore, the respective contributions of $\mathrm{Hg}$ emissions from anthropogenic and natural sources are not fully constrained and the long-term influence of climate variability is still in debate. In this study, we reconstructed $\mathrm{Hg}$ depositions over the last 13,500 years based on two sedimentary records located at the fringe between Amazonia and the Altiplano. Multiproxy analyses carried on the same sedimentary archives (i.e. $\mathrm{Hg}$ accumulation rates (AR), major elements, total organic carbon, $\delta^{13} \mathrm{C}$ and pollen analyses) show evidence that $\mathrm{Hg}$ deposition has risen according to Amazonian orographic moisture and precipitation during the Holocene, except for the last 200 years, for which modern industry and goldmining overwhelmed the natural signal. Comparisons with existing $\mathrm{Hg}$ records indicated that metallurgy and volcanic emissions were not perceptible due to the eastern down-wind position of the sites. Altogether, it argues that the historical variability of $\mathrm{Hg}$ deposition in the central eastern Andes has been primarily driven by changes in Amazonian moisture. At least six main phases of higher $\mathrm{Hg}$ AR $\left(2.6 \pm 1.4 \mu \mathrm{g} \mathrm{m}^{-2} \mathrm{y}^{-1}\right)$ compared to baseline values $\left(0.9 \pm 0.3 \mu \mathrm{g} \mathrm{m}^{-2} \mathrm{y}^{-1}\right)$ were identified over the Holocene. During the early and late Holocene, phases of higher Hg AR coincided with wet episodes recorded in Lake Titicaca and Sajama records. During the Middle Holocene arid phase, reconstructed wetter episodes by $\mathrm{Hg}$ together with vegetation dynamics were attributed to the set-up of moisture niches in the eastern flanks of the Andes. Comparisons to other paleoclimatic records supports the role of North Atlantic sea-surface temperature in forcing precipitation during the late Holocene period while other mechanisms allowing moisture niches by orography are discussed for the Mid-Holocene dry phase in the eastern Andes region.
\end{abstract}

\section{Introduction}

Due to its relatively long residence time in the atmosphere $(\sim 0.5$ to 1 year), mercury $(\mathrm{Hg})$ is ubiquitous in the atmosphere (Fitzgerald et al., 2014). The transport of $\mathrm{Hg}$ is therefore regional to global, depending on chemical environments in the atmosphere and on different physical and meteorological processes (Pirrone et al., 2009). Atmospheric Hg originates from both natural direct emission (e.g., volcanoes and weathering) and re-emission (e.g., from the ocean, soils and forests) of geogenically derived $\mathrm{Hg}$ to which are added anthropogenic emissions mainly resulting from industrial sources, fossil fuel combustion and goldmining which affect the magnitude and timing of re-emissions from environmental reservoirs (Amos et al., 2015; Fitzgerald and Mason, 1994; Pirrone and Mason, 2009).

Centuries of anthropogenic $\mathrm{Hg}$ releases have resulted in a global legacy of $\mathrm{Hg}$ contamination in the atmosphere with wet and dry depositions as a major source of $\mathrm{Hg}$ for terrestrial surfaces (Fitzgerald et al., 2014). In the northern hemisphere, notwithstanding the remoteness of the site, the human imprint is evident in sedimentary archives for more than the past 800 years. $\mathrm{Hg}$ accumulation rates (AR)

\footnotetext{
* Corresponding author at: Univ. Grenoble Alpes, Univ. Savoie Mont Blanc, CNRS, IRD, IFSTTAR, ISTerre, 38000 Grenoble, France. E-mail address: stephane.guedron@ird.fr (S. Guédron).
} 
have risen from a natural background of 0.5 to $4 \mu \mathrm{g} \mathrm{m}^{-2} \mathrm{y}^{-1}$ in the prehistorical times by a factor of $\sim 5$ during the Middle Ages mostly due to mining activities and up to $\sim 20$ during the industrial era (Allan et al., 2013; Amos et al., 2015; Givelet et al., 2003; Guédron et al., 2016; Roos-Barraclough et al., 2002b; Shotyk et al., 2003; Thevenon et al., 2011). From this latter period, a rise in atmospheric Hg background was observed in both hemispheres such as in remote South American archives in which $\mathrm{Hg}$ ARs were 2 to 4-fold higher than pre-anthropogenic values highlighting the long range atmospheric transport of $\mathrm{Hg}$ (Biester et al., 2002; Lacerda et al., 1999, 2017). However, historical episodes of large anthropogenic $\mathrm{Hg}$ emissions were not always recorded at the global nor at regional scale such as the Spanish Silver era in the central Andes (from 1574 to $1820 \mathrm{CE}$ ) likely due to atmospheric circulation (i.e., easterlies) which limited their record to lakes located downwind of the sources (Beal et al., 2013; Cooke et al., 2011, 2013; Robins and Hagan, 2012).

In South America, millennial-scale $\mathrm{Hg}$ records of the pre-mining period are scarce. Available sequences have shown $\mathrm{Hg}$ AR decreases during dry episodes compared to wetter ones (Barbosa et al., 2004; Biester et al., 2002; Lacerda et al., 1999, 2017; Santos et al., 2001). Although these authors have not demonstrated the mechanisms implied in these fluctuations, they attributed them to volcanism or paleoclimatic factors including changes in precipitation, forest fires, and abundance of predominant plant species that have changed the efficiency by which $\mathrm{Hg}$ was captured. So far, the explanation of climatically significant variation on paleoclimate time scales is still in debate. Summer moisture in tropical South America originates mainly from the South American Summer Monsoon (SASM). The trade winds from the tropical Atlantic Ocean provide the moisture to the Andean region during the austral summer (November to March), whose transport intensifies locally along the eastern scarp of the Andes (Liebmann and Mechoso, 2011). The spatiotemporal variability of precipitation in the Central Andes (14-21 ${ }^{\circ} \mathrm{S}$ ) has led to extreme events which were recorded in Lake Titicaca such as a major drop in lake level of $>70 \mathrm{~m}$ during the Middle Holocene (i.e., MH from $\sim 8500$ to $\sim 4000$ yrs cal BP) period (Fritz et al., 2006; Mourguiart et al., 1997; Rowe et al., 2003). On the one hand, some authors attributed the long-term (e.g., multi-decadal to millennial) drought or flood cycles as a response of higher frequency of El Niño-like or El Niño Southern Oscillation (ENSO) - like events (Moy et al., 2002; Rodbell et al., 1999). On the other hand, other authors concluded that at least the past 7000 yrs. ENSO variance was slightly different from the modern one, suggesting the absence of any influence for long-term drought or flood cycles in the SASM region and rather supported the Atlantic Meridional Overturning Circulation (AMOC) as main driver (Baker and Fritz, 2015; Masson-Delmotte et al., 2013). For this latter, it was suggested that for long timescales, low temperatures in the high-latitude North Atlantic accompanied by high surface pressures in the Bermuda High and stronger northeasterly trades could cause anomalously cold sea-surface temperatures (SSTs) in the tropical North Atlantic and a southward shift of the mean annual position of the Inter Tropical Convergence Zone (ITCZ). Such anomalously strong northeasterly trades could bring about increased precipitation in the southern tropics of South America, including much of the Amazon and tropical Andes (Baker et al., 2009). Ocean-atmosphere-vegetation coupled models (Braconnot et al., 2007a, 2007b) and palaeodata syntheses (Prado et al., 2013a, 2013b) have also established that changes in tropical Atlantic SST gradient and in summer insolation weakened the SAMS circulation over the South Atlantic Convergence Zone area during the Middle Holocene compared to the Late Holocene (Seillès et al., 2016).

Present day measurements have indicated that rain is a significant source of $\mathrm{Hg}$ (unfiltered $\mathrm{THg}=5.9 \pm 3.1 \mathrm{ng} \mathrm{L}^{-1}$ ) to the Lake Titicaca (Guédron et al., 2017). Due to its orography, the Andean Cordillera acts as a climate barrier, blocking low-level air masses from the equatorial Atlantic and focusing precipitation along its eastern flank by local-scale moist convection (Garreaud et al., 2003; Roche et al., 1992). Thus, it is likely that the Atlantic air masses supply the Andean Cordillera in moisture and $\mathrm{Hg}$. These air masses are also likely enriched in re-emitted $\mathrm{Hg}$ during their path over the Amazonian rainforest whose $\mathrm{Hg}$ geochemical background is naturally high (Demers et al., 2013; Graydon et al., 2006; Guédron et al., 2018, 2009). Moreover, recent studies have demonstrated that $\mathrm{Hg}$ deposition and accumulation in mountain soils is increased with elevation by both higher precipitations and lower temperatures that enhance orographic cloudwater formation and thus favor Hg dry and wet deposition (Stankwitz et al., 2012; Zhang et al., 2013).

In this study, we measured $\mathrm{Hg}$ concentrations and calculated $\mathrm{Hg} \mathrm{AR}$ in two high altitude ( $>3700 \mathrm{~m}$ a.s.l.) sediment archives sampled in the Eastern Cordillera of Bolivia, between Amazonia and the Altiplano. To evaluate the contribution of Amazon moisture as a source of $\mathrm{Hg}$ for the central Andes, we first compared those results to (i) the abundance of pollen grains transported from the Andean forest (or Yungas) to the Puna with Amazonian convective moist activity and (ii) changes in $\delta^{13} \mathrm{C}$ values of C3 herbaceous plants that are driven by annual precipitation, both measured on the same sediment cores (Escobar-Torrez et al., 2018; Ledru et al., 2013; Ortuño et al., 2011). Then, we compared our data to several paleoenvironmental archives in order to test the pertinence of this new proxy in regards of the spatiotemporal trends in precipitations and other natural or anthropogenic $\mathrm{Hg}$ emission. Finally, we compared our dataset with other paleoclimatic proxies to identify and discuss potential drivers of the South American Summer Monsoon.

\section{Material and methods}

\subsection{Study site information and peat sampling}

The Escalerani and Tiquimani study sites are located at the frontier between Amazonia and the Cordillera Real in Bolivia (Fig. 1 and S.I. 1). This area is characterized by a wet (December to February) and a dry (June to August) season. Because of the high-altitude ( $>3700 \mathrm{~m}$ a.s.1.) mean temperatures rarely exceed $7{ }^{\circ} \mathrm{C}$ (Escobar-Torrez et al., 2018; Ledru et al., 2013). The study sites are located on the wet Puna vegetation belt (Escobar-Torrez et al., 2018; Ledru et al., 2013), characterized by open landscapes made of grasslands and shrublands. The upper Montane Yungas vegetation belt extends on steep slopes between 3100 and $4200 \mathrm{~m}$ a.s.l. where the clouds frequently collide with forest and humid conditions prevail all year (mean annual precipitation is > $1500 \mathrm{~mm}$ ). At lower altitude, the Yungas (i.e., Oriental Andes, between 1000 and $4200 \mathrm{~m}$ a.s.1.) are covered by evergreen forests. The Escalerani wetland has an elevation of $4040 \mathrm{~m}$ a.s.l. $\left(15^{\circ} 50^{\prime} 42^{\prime \prime} \mathrm{S}\right.$, $68^{\circ} 16^{\prime} 35.5^{\prime \prime} \mathrm{W}$ ) and is located $\sim 60 \mathrm{~km}$ from Lake Titicaca and $4 \mathrm{~km}$ from the Yungas forest. The wetland is drained by a perennial river that originates from an almost extinct glacier, today $800 \mathrm{~m}$ above the wetland. Two sediment cores namely ESC (15 50' 41.701"S, $68^{\circ} 16^{\prime}$ $\left.53.601^{\prime \prime} \mathrm{W}\right)$ and ET3 (15 $\left.50^{\prime} 43.159^{\prime \prime} \mathrm{S}, 68^{\circ} 16^{\prime} 53.007^{\prime \prime} \mathrm{W}\right)$ were collected at depths of 1.0 and $1.63 \mathrm{~m}$ with a Russian corer in November 2013 (Escobar-Torrez et al., 2018) and November 2014 (this study), respectively. The Tiquimani wetland $\left(16^{\circ} 12^{\prime} 06.8^{\prime \prime} \mathrm{S}, 68^{\circ} 3^{\prime} 51.5^{\prime \prime} \mathrm{W}\right)$ is located at an elevation of $3760 \mathrm{~m}$ a.s.l. in the Puna at the head of an inter-Andean valley at $2.3 \mathrm{~km}$ from the Yungas forest. A $36 \mathrm{~cm}$ core (TK 1-2) was collected with a Russian corer in a small wetland in July 2005 (Ledru et al., 2013).

All cores were wrapped in a plastic film and stored in a half plastic tube at $4{ }^{\circ} \mathrm{C}$ until slicing. Sediment lithology was first described and cores were sampled at $1 \mathrm{~cm}$ intervals using plastic foiled metallic slicers. Samples were wrapped and stored in PVC foils in a cool room at $4{ }^{\circ} \mathrm{C}$ until being freeze-dried and crushed to obtain a size smaller than $63 \mu \mathrm{m}$ for elemental analysis.

\subsection{Chemical analysis}

Details for sample preparation and chemical analysis are given in S.I.1. Briefly, XRF analysis on the ET3 core was performed on the fresh 


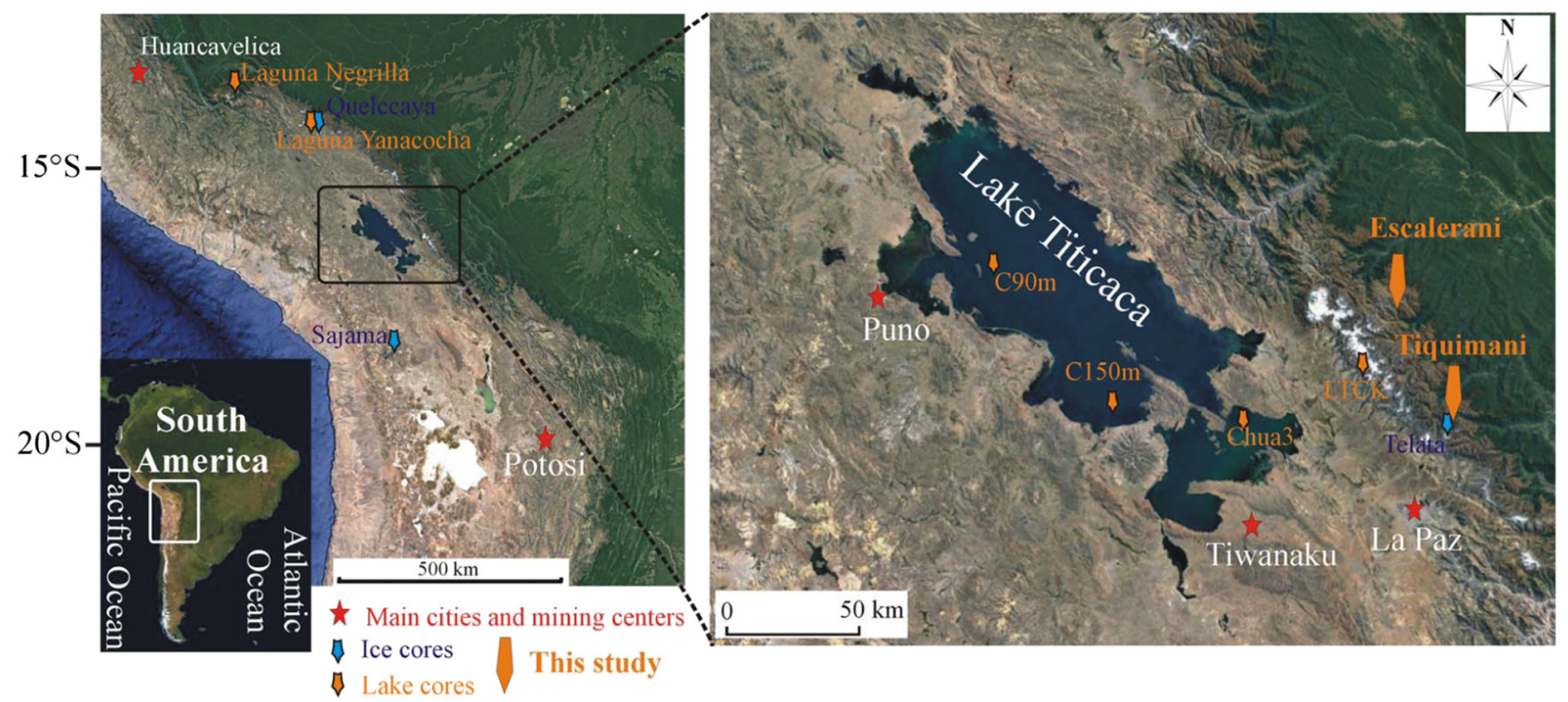

Fig. 1. Location of Escalerani and Tiquimani study sites (yellow symbols) in the Eastern Cordillera, Lake Titicaca, and main cities and pre-Columbian occupation and mining centers (red symbols). Are also presented the location of published ice cores from Telata, Quelccaya and Sajama glaciers (blue symbols)) and sediment cores of Laguna Taypi Chaka Khota (LTCK), Laguna Negrilla, Laguna Yanacocha and Lake Titicaca (C150m, C90m and Chua 3 - orange symbols). (For interpretation of the references to colour in this figure legend, the reader is referred to the web version of this article.)

surfaces of sub-sampled U-channels $(2 \mathrm{~cm}$ section) with a $5 \mathrm{~mm}$ resolution using a non-destructive Avaatech core-scanner. Geochemical data were obtained at different tube settings, $10 \mathrm{kV}-2 \mathrm{~mA}$ for Al, Si, Ca, $\mathrm{Ti}$, Fe and at $30 \mathrm{kV}-0.5 \mathrm{~mA}$ for $\mathrm{Zn}, \mathrm{Sr}$, and Rb (Richter et al., 2006).

Total mercury concentrations ([THg]) were determined by combustion and atomic absorption spectrophotometry using an AMA 254 analyzer (Altec) (Guédron et al., 2009; Roos-Barraclough et al., 2002a). QA/QC was checked by repeating the analysis of the CRM MESS-3, and concentrations found $\left(90.3 \pm 2.1 \mathrm{ng} \mathrm{g}^{-1}, \mathrm{~N}=22\right)$ agreed with the certified concentration $\left(91 \pm 8 \mathrm{ng} \mathrm{g}^{-1}\right.$ ). The analytical quality for $\mathrm{THg}$ measurements was assured by analyzing several samples twice with measurement error on replicates $(\mathrm{N}=52)$ of about $5 \%$ and always below $10 \%$. Hg accumulation rates ( $\mathrm{Hg} \mathrm{AR}$ ) were obtained from $\mathrm{THg}$ concentration, dry bulk density (DBD) and age period covered by each slice. Hg AR could not be obtained from the TK 1-2 core since samples had dried during storage rendering unable the measurement of DBD.

All details for pollen, carbon stable isotopes and total nitrogen analyses are given in Ledru et al. (2013) and Escobar-Torrez et al. (2018).

\subsection{Dating and age-depth model}

Eight radiocarbon dating were performed on core ET3 at the Laboratoire de Mesure du Carbone 14 by accelerator mass spectrometry radiocarbon dating (Table 1 ). All the radiocarbon ages were calibrated to calendar years Before Present (cal. yr BP) using the calibration curve

Table 1

Radiocarbon ages performed on bulk sediment of core ET3.

\begin{tabular}{lllll}
\hline Laboratory code & Depth $(\mathrm{cm})$ & $\delta^{13} \mathrm{C}(\%)$ & ${ }^{14} \mathrm{C}$ age (yr BP) & $\begin{array}{l}\text { Age 2 } \sigma \text { range } \\
(\text { cal yr BP) }\end{array}$ \\
\hline SacA 45003 & $8-9$ & -27.8 & $510 \pm 30$ & $493-540$ \\
SacA 45004 & $24-25$ & -29 & $2105 \pm 30$ & $1931-2145$ \\
SacA 45005 & $50-51$ & -31.5 & $4220 \pm 30$ & $4580-4832$ \\
& & & & (excluded) \\
SacA 45006 & $69-70$ & -25.7 & $3805 \pm 30$ & $3989-4239$ \\
SacA 45007 & $85-86$ & -31.2 & $3960 \pm 30$ & $4239-4438$ \\
SacA 45008 & $97-98$ & -27.1 & $9526 \pm 40$ & $9476-9621$ \\
SacA 45009 & $135-136$ & -25.7 & $10,728 \pm 45$ & $10,664-11,088$ \\
SacA 45010 & $159-160$ & -22 & $13,272 \pm 50$ & $13,204-13,444$ \\
\hline
\end{tabular}

for the Southern Hemisphere SHCal13 (Hogg et al., 2013) and with the Southern Hemisphere postbomb curves from Hua et al. (2013).

Construction of the age-depth model was performed by running the 'CLAM' version 2.2 (Blaauw, 2010) under the software ' $R$ ', taking into account the density probability of the ${ }^{14} \mathrm{C}$ ages (Marsh et al., 2018). The best age-depth model and its $95 \%$ confidence interval have been estimated using a monotonic smooth spline interpolation (type 4) calculated 10,000 times (Fig. 2). Age-depth models of TK 1-2 and ESC are published in Ledru et al. (2013) and Escobar-Torrez et al. (2018) and reported in Fig. 2. Radiocarbon ages of core TK 1-2 have been recalibrated with the most recent calibration curve (SHCal13), providing a chronology comparable to core ET3 and ESC (S.I.2).

\section{Results and interpretation}

\subsection{Set up and evolution of Escalerani peat bog}

The sediment cores collected at Escalerani consists in an alternation of peat and dark or light beige silt-clay sediments (Fig. 2). The stratigraphic succession of facies partly corresponds between the two cores, characterized by black silt-clay from 0 to $20 \mathrm{~cm}$, followed by lightbrown silt-clay (20-35.7 cm in ET3 and $20-39 \mathrm{~cm}$ in ESC), and then by a more organic facies made of a fibrous brown peat in ET3 (up to $86 \mathrm{~cm}$ ). The latter is laterally related to black silt-clay in ESC (up to $55 \mathrm{~cm}$ ). From these depths to core bottoms, the sediment succession differs. ESC is characterized by light-brown silt-clays followed by peat while ET3 presents a sedimentological discontinuity to the underlying light-beige silt-clay sediments (Fig. 2), with a sharp erosional contact consisting in a sand layer $(86-96 \mathrm{~cm})$.

ET3 facies succession corresponds to change in dry bulk density (DBD) as well as of the relative peak intensities in major elements (Fig. 2 and S.I. 2). High DBD and Si are measured in the light-beige siltclay facies, reaching a peak in the sandy layer. Moderate DBD and Si values occur in the light-brown silt-clay facies, and the lowest ones in the black silt-clay facies. Si and DBD, similarly to the well-correlated lithogenic elements (e.g. $\mathrm{Ti}, \mathrm{Rb}$ ) track relative variations of the minerogenic detrital fraction originating from glacier abrasion upstream. Detrital sediments alternate with organic sediments during phases of low sedimentation and reduced detrital deposition. Besides a similar general sedimentological pattern, differences exist between ET3 and 


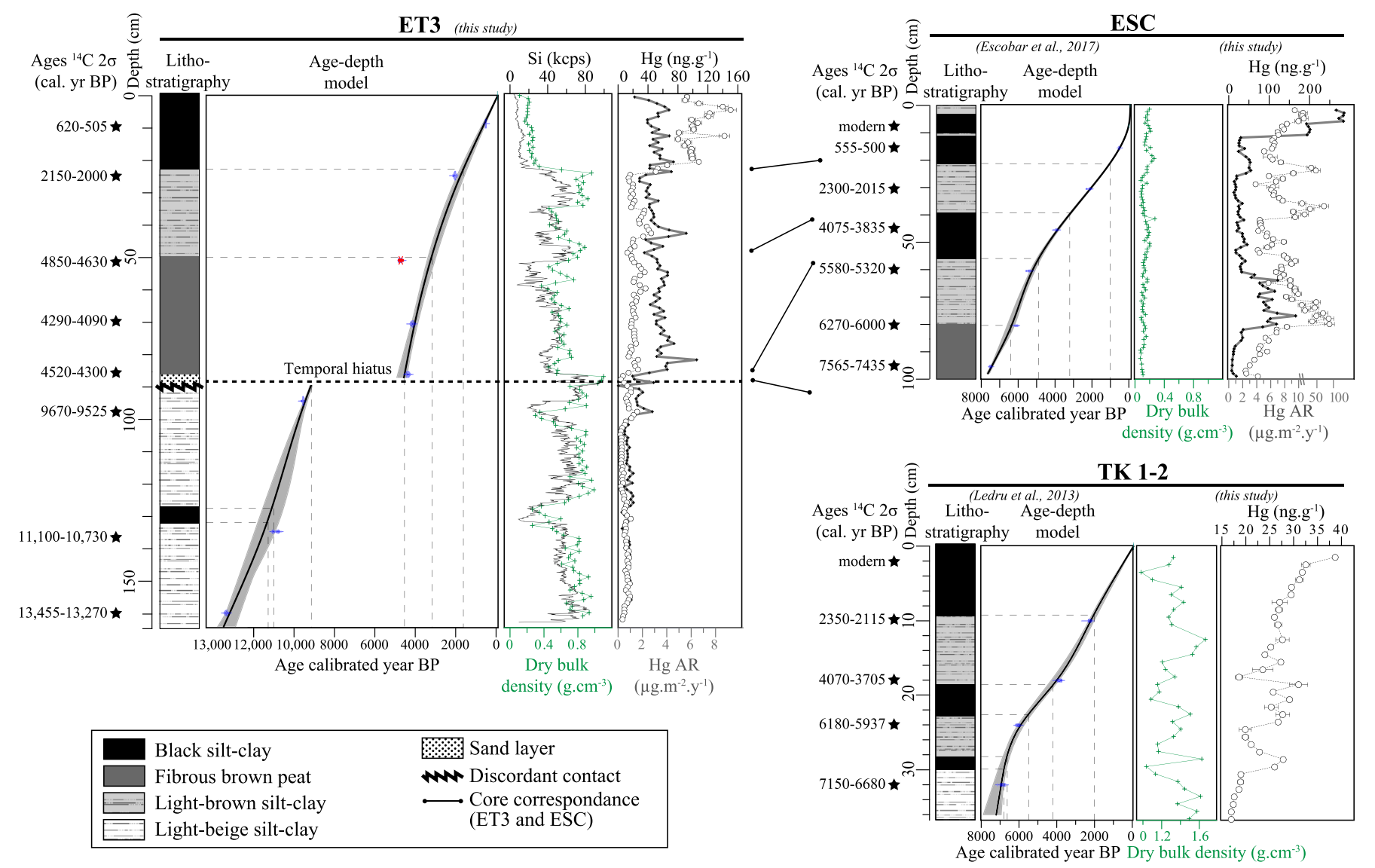

Fig. 2. Lithostratigraphy, age-depth relationship and position of the radiocarbon ages, dry bulk density, mercury concentration (Hg) and accumulation rate (Hg AR), and Silicium abundance (Si) reported according to the three investigated cores of the Escalerani (ET3 and ESC) and Tiquimani wetlands (TK1-2).

ESC. Between 39 and $55 \mathrm{~cm}$, ESC depicts a facies composed of fine and dark peat layers with a homogenous DBD $\left(0.1 \mathrm{~g} \mathrm{~cm}^{-3}\right)$, while ET3 has a more fibrous peat facies enriched in detrital materials $(50-86 \mathrm{~cm})$ with higher DBD (average of $0.6 \mathrm{~g} \mathrm{~cm}^{-3}$ ). Taking into account that ESC is situated in a distal position to the main river channel compared to ET3, it is very likely that ET3 has been subject to higher detrital inputs as illustrated by sharp rises in DBD, sedimentation rates, and elemental distribution. Due to its proximity to the glacier tongue, it is likely that the valley of Escalerani was characterized by a glacial outwash plain in which an anastomosed river network was developing, inducing lateral variation in sediment facies depending to the proximity of the coring site to the river stream.

Based on results of the age-depth models (Fig. 2), the core ESC provides a continuous accumulation over the last $7530-7730$ years $(2 \sigma$ interval), with a mean sedimentation rate of $0.02 \mathrm{~cm} \mathrm{yr}^{-1}$. In the case of ET3, taking into account the relative position of ${ }^{14} \mathrm{C}$, we excluded the sample SacA 45005 that probably results of reworking material from the catchment. The sediment discordance observed between 86 and $96 \mathrm{~cm}$ (sandy layer) corresponds to a hiatus of sedimentation ranging

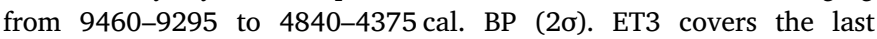
$13,290-12,580$ cal. BP $(2 \sigma)$. This results in sedimentation rates of 0.01 from core bottom to $96 \mathrm{~cm}, 0.02 \mathrm{~cm} \mathrm{yr}^{-1}$ from 85 to $22 \mathrm{~cm}$, and again $0.01 \mathrm{~cm} \mathrm{yr}^{-1}$ from $22 \mathrm{~cm}$ to the top core.

Altogether, the results indicate that from 13,100 to 9400 cal. BP (best modeled ages), Escalerani was subjected to an abundant detrital supply, that has been then truncated in the coring site location probably because of lateral river erosion (core ET3). Our record restarted at $7560 \mathrm{cal}$. BP (core ESC) by the appearance of more organic sediments attesting to a decrease in the influence of the glacier detrital supply at both coring sites. From 7650 to $1500 \mathrm{cal}$. BP at ET3 and $1000 \mathrm{cal}$. BP at
ESC, the lateral facies variations, together with alternation of organicrich to -poor facies suggests a heterogeneity of the sedimentation at the scale of the alluvial plain, depending on the proximity to the river streams. Today, a perennial river stream is highly incised in its Late Glacial-Holocene deposits for about $1 \mathrm{~m}$-deep, disconnecting the top of the wetland to the river activity, and explaining the development of a black organic facies measured from 1500 cal. BP to Present.

\subsection{Mechanisms of $\mathrm{Hg}$ deposition and temporal variability with precipitations}

Highest $\mathrm{Hg}$ concentrations (i.e., up to $250 \mathrm{ng} \mathrm{g}^{-1}$ ) are found in peat layers known to provide long-term records of $\mathrm{Hg}$ supplied almost exclusively by the atmosphere since it strongly adsorbs and complexes both $\mathrm{Hg}^{\mathrm{O}}$ and $\mathrm{Hg}^{2+}$ incoming from both dry and wet depositions (Enrico et al., 2017, 2016; Shotyk et al., 2005). The recycling of atmospheric $\mathrm{Hg}$ and its incorporation into peat sediments occur through different mechanisms including cloudwater that scavenges $\mathrm{Hg}$-bearing particulates from the lower troposphere (Lawson et al., 2003), convective storms which are effective at trapping reactive gaseous mercury from the upper atmosphere (Guentzel et al., 2001), and the incorporation of gaseous elemental $\mathrm{Hg}$ through stomata and across cuticle (Enrico et al., 2016; Guédron et al., 2013). Regardless of the mechanism of deposition, $\mathrm{Hg}$ is then mostly incorporated into the sulfur-bearing group of the organic matter (Andersson, 1979; Fitzgerald et al., 2014; Nagy et al., 2007).

To determine if $\mathrm{Hg}$ depositions are enhanced by Amazon moisture in the central Andes, we compared our $\mathrm{Hg}$ data with both the abundance of pollen grains and $\delta^{13} \mathrm{C}$ (Fig. 3) that were identified as proxies of convective moisture in the region (Escobar-Torrez et al., 2018; Ledru 
$\begin{array}{rr}\text { Ages }{ }^{14} \text { C 2 } \sigma & \text { Escalerani } \\ \text { (cal. yr BP) } & \text { Core ESC }\end{array}$

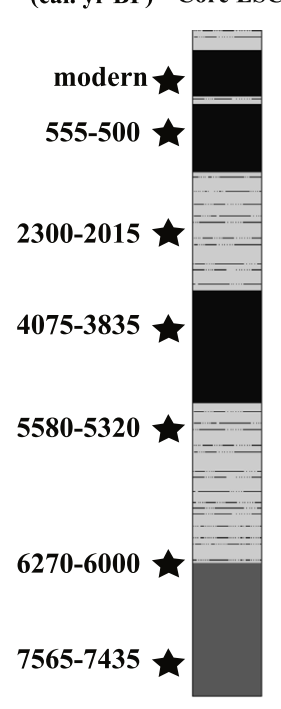

Ages ${ }^{14} \mathrm{C} 2 \sigma$ Tiquimani

(cal. yr BP) Core TK 1-2

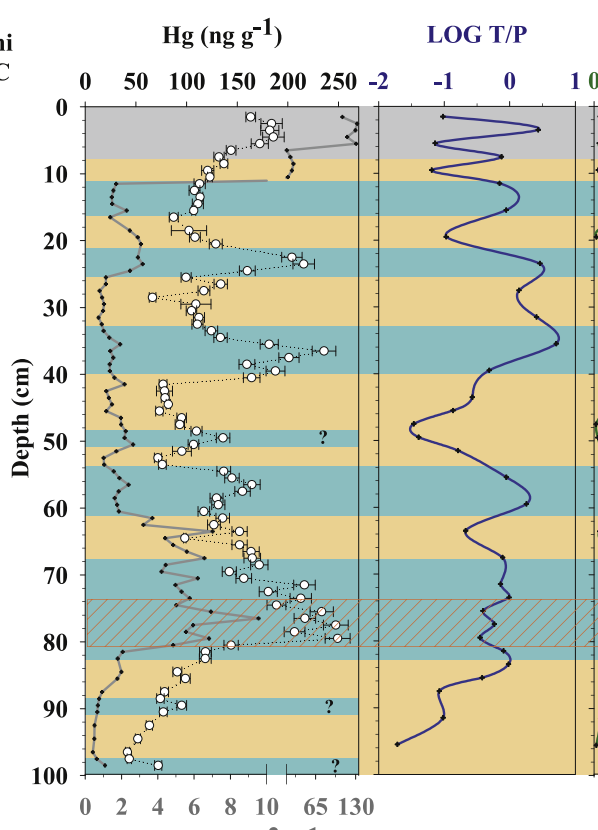

$\operatorname{Hg} \operatorname{AR}\left(\mu \mathrm{g} \mathrm{m}^{-2} \mathrm{y}^{-1}\right)$
Yungas Taxa (\%)

$\delta^{13} \mathrm{C}$ $\begin{array}{llllllllll}1 & 0 & 20 & 40 & 60 & 80 & -28 & -27 & -26 & -25\end{array}$

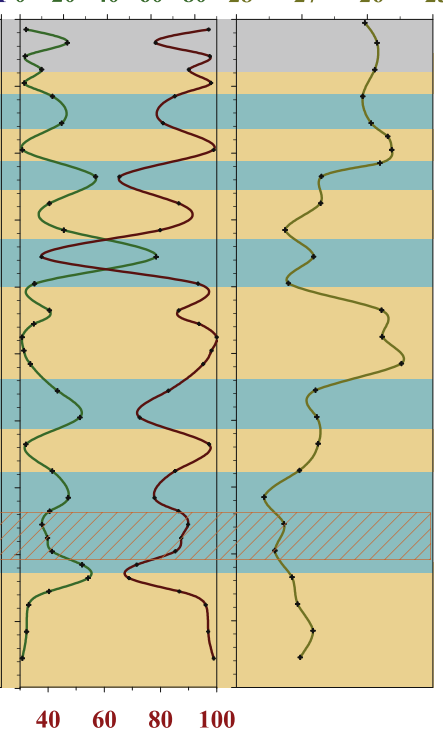

Wet PunaTaxa (\%)
Fig. 3. Depth profiles of mercury concentration $([\mathrm{Hg}])$ and accumulation rate (Hg AR), log Transported pollen/Poaceae (T/P), Yungas (from the Amazon) and wet Puna (from the watershed) pollens counts and $\delta^{13} \mathrm{C}$ for Escalerani ESC (upper panels) and Tiquimani (downer panels) cores. Data for pollens and $\delta^{13} \mathrm{C}$ are from Ledru et al. (2013) and Escobar-Torrez et al. (2018). Grey bands underlines the modern period (last 200 years), blue bands the wet phases and light orange bands the dry episodes. Superimposed red rectangles indicate the periods of peat set-up. (For interpretation of the references to colour in this figure legend, the reader is referred to the web version of this article.)

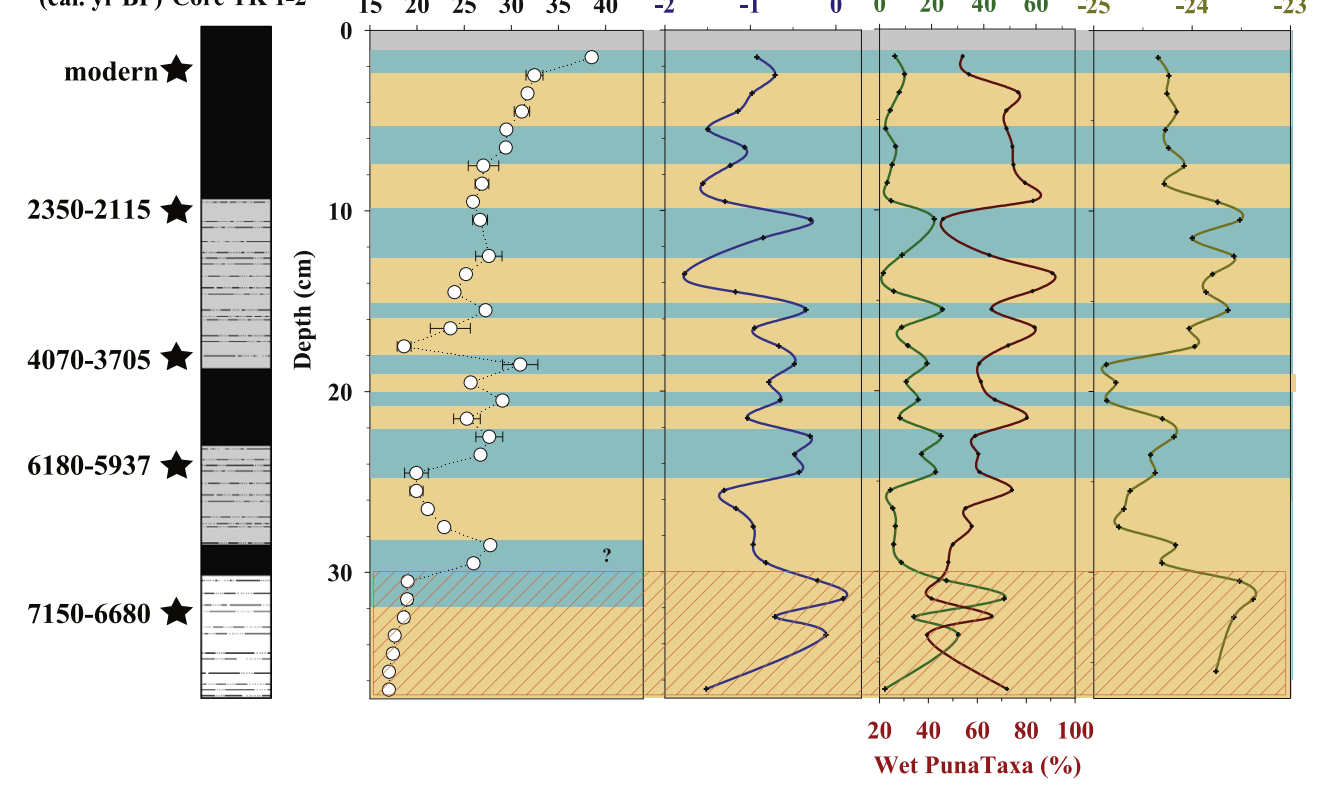

et al., 2013; Ortuño et al., 2011). Pollen associated with Yungas vegetation species are transported from the Amazonian vegetation belt by the wind and deposited on the bog by cloud dripping while Poaceae pollens originate from the local wet Puna vegetation belt (Fig. 1). Hence, both Transported pollen/Poaceae (T/P) index and Yungas taxa are indicators of the historical changes in precipitation regimes in the central Andes during the Holocene (Escobar-Torrez et al., 2018; Ledru et al., 2013; Ortuño et al., 2011). Hg concentration profile shows positive correlations with $\log \mathrm{T} / \mathrm{P}$ in Escalerani (ESC, $\mathrm{R}=0.61$, $\mathrm{p}<0.05$ ), highlighting that in this record, $\mathrm{Hg}$ deposition rises with moisture coming from the Amazon Basin (Fig. 3 and S.I.3). This relationship is less significant for the entire Tiquimani record $(R=0.34$, $\mathrm{p}<0.05$ - S.I.3). Positive correlations are not verified for the surface samples (last 150 years), at $50 \mathrm{~cm}$ in ESC, at the bottom of ESC $(60-80 \mathrm{~cm})$, and at $32-37 \mathrm{~cm}$ in TK $1-2$ (S.I. 3) for different reasons that are detailed later in the discussion.
In addition to pollen, changes in $\delta^{13} \mathrm{C}$ values of $\mathrm{C} 3$ herbaceous plants are driven by annual precipitation, water availability in soil and evapotranspiration (Escobar-Torrez et al., 2018; Ledru et al., 2013; Wang et al., 2003). C3 plants growing under water-stressed conditions are expected to be enriched in ${ }^{13} \mathrm{C}$ compared with plants growing under optimal water conditions (Farquhar and Sharkey, 1982). When plotted against $\delta^{13} \mathrm{C}, \mathrm{Hg}$ concentrations in ESC show a negative correlation $(\mathrm{R}=-0.46, \mathrm{p}<0.05-\mathrm{S} . \mathrm{I} .3 \mathrm{c})$ confirming that $\mathrm{Hg}$ deposition is enhanced during wet period at Escalerani. At Tiquimani, such correlation is not verified when $\mathrm{Hg}$ is plotted against $\delta^{13} \mathrm{C}, \mathrm{T} / \mathrm{P}$ index or Yungas pollen, suggesting that $\mathrm{C}$ fractionation is controlled by other processes and/or diluted by another source.

At Escalerani, lowest $\mathrm{Hg}$ concentrations are measured in periods of low convective moisture characterized by low log T/P and high $\delta^{13} \mathrm{C}$ values. In the meantime, these periods are characterized by rises in DBD (core ESC) together with both wet Puna pollen taxa and Poaceae (i.e., 


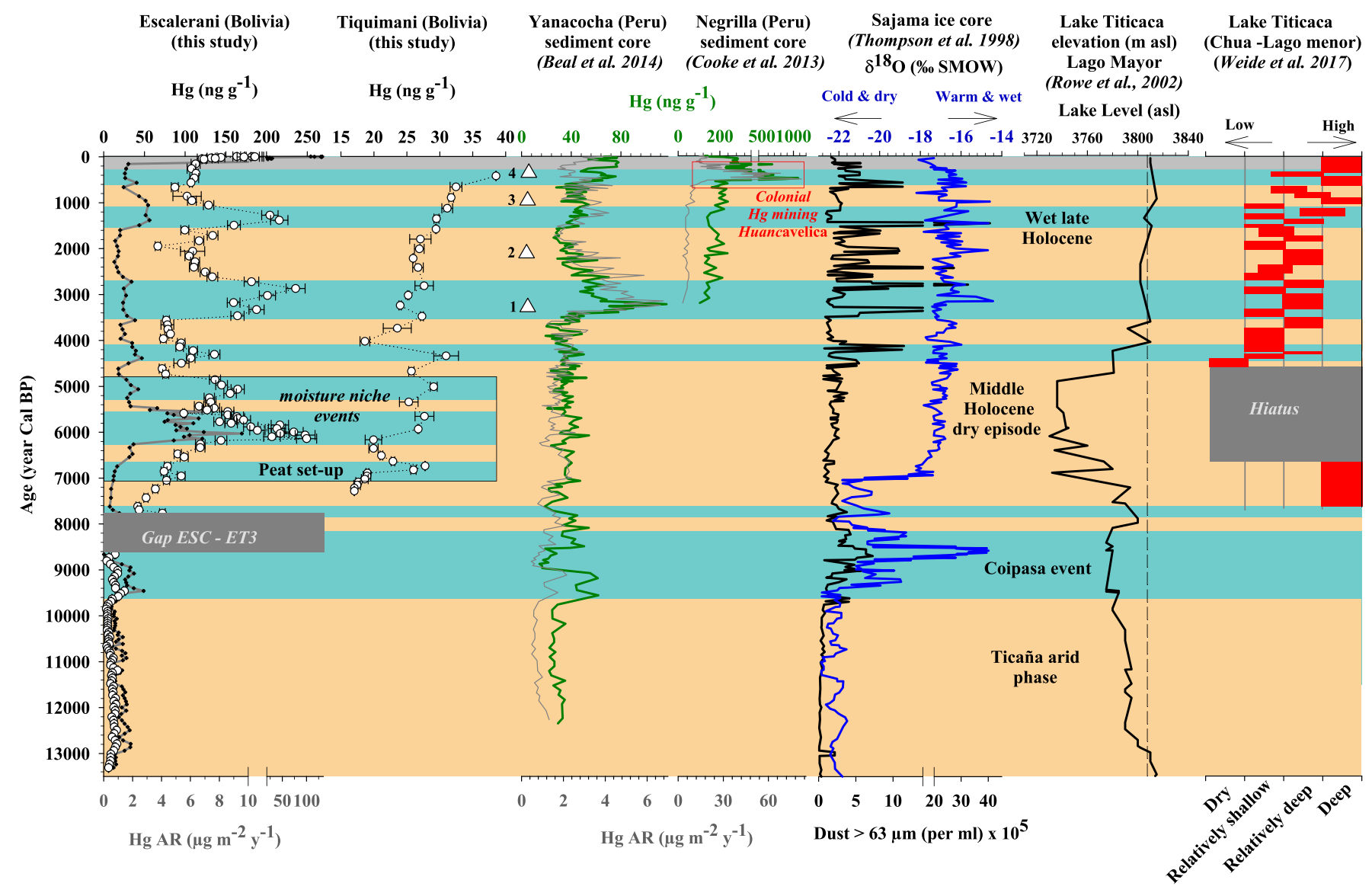

Fig. 4. (From left to right) age scale plotted vertical profiles of $\mathrm{Hg}$ concentrations and accumulation rates (Hg AR) in Escalerani and Tiquimani cores (this study) and their comparison with Hg profiles of Yanacocha laguna (Beal et al., 2014), $\delta^{18} \mathrm{O}$ (\% SMOW) profiles from the Sajama ice record (Peru - Thompson et al., 1998) and water-level fluctuations in the Lake Titicaca for the great lake (Rowe et al., 2002) and lake minor inferred from diatom analysis (Weide et al., 2017). Blue layers refer to wetter episodes, light orange to dryer episodes and grey to modern global warming and anthropogenic emissions. Also shown (white triangle) are volcanic eruptions with a Volcanic Explosivity Index of $\geq 4$ in the Andean Cordillera Volcanic Zone during the last 4 kyrs BP with (1) Yucamane, (2) El Misti, (3) Ubinas and (4) Huaynaputina (Siebert and Simkin, 2013). (For interpretation of the references to colour in this figure legend, the reader is referred to the web version of this article.)

pollens originating from the watershed - Fig. 3) confirming that when the peat is fed by water from glacier melting, higher detrital inputs make the sediment DBD to rise. Hence, during drier periods, glacier melting is the main water supply to the wetland and the associated $\mathrm{Hg}$ inputs from melting waters and transported fine particles are weak. This is also the case for the silty clayed mineral rich basal units of our records deriving from local eroded rocks and soils of the watershed where concentrations are the lowest (i.e., 5 to $25 \mathrm{ng} \mathrm{g}^{-1}$ ) confirming that $\mathrm{Hg}$ inputs from the watershed are low. Hence, the relative abundance of mineral and organic matrix explains the difference in mean THg concentrations measured between the two cores at Escalerani.

\subsection{Assessment of the peat geochemical records}

It is now accepted that both peat and lake sediment archives provide comparable and consistent historical Hg records (Amos et al., 2015). However, previous studies established key areas that need careful attention in assessing the peat geochemical record including reliability of chronology, reliability between records, and diagenetic effects on the geochemical record (Amos et al., 2015; Biester et al., 2007, 2002; Bindler, 2006).

At Escalerani, ranges of $\mathrm{Hg}$ concentrations, $\mathrm{Hg}$ ARs and their temporal variations are in agreement for cores ESC and ET3 along the Holocene, showing that both $\mathrm{Hg}$ records and age models are reliable (S.I.3). However, this is not verified for the modern period due to insufficient number of dates for the upper part of core ET3 which do not provide accurate sedimentation rates for the last centuries.

The main difference found between Escalerani and Tiquimani $\mathrm{Hg}$ records is attributable to diagenetic evolutions. In Tiquimani (core TK 1-2), $\mathrm{Hg}$ concentrations are highly correlated to Total Organic Carbon (TOC $-\mathrm{R}=0.8, \mathrm{p}<0.01-$ S.I.3) and both $\mathrm{Hg}$ and TOC are 2 to 10 times lower than in core ESC (Fig. 3 and S.I.3). In the ESC profile, Hg concentrations do not correlate with TOC (S.I. 3) likely due to a large abundance of the latter ( 5 orders of magnitude greater than $\mathrm{Hg}$ ) which is not limiting for $\mathrm{Hg}$ accumulation. In addition, while ESC core exhibits large range of $\mathrm{C} / \mathrm{N}$ (13 to 60 ) and $[\mathrm{Hg}]$ without any correlation between both parameters, TK 1-2 has a narrow C/N range (10 to 16$)$ and $[\mathrm{Hg}]$ decreases with rising C/N (S.I.3). Hence, this makes the ESC record more sensitive and accurate for a continuous record of long-term atmospheric $\mathrm{Hg}$ deposition than TK 1-2 where $\mathrm{Hg}$ accumulation is likely influenced by the decomposition of peat and the subsequent $\mathrm{C}$ loss. Finally, when comparing Escalerani to Tiquimani, some differences exist for the distribution of pollens and $\mathrm{Hg}$ concentration between cores that can be ascribed to their respective topographical positions. The northern Escalerani site is located at a high altitude glacier watershed (4040 m a.s.l. for ESC core) suggesting a delayed set-up of the peat compared to the southern and lower altitude Tiquimani wetland (TK 1-2, $3760 \mathrm{~m}$ a.s.l.). It is also probable that the northern Escalerani site is exposed to higher convective moisture and Hg supply since both are enhanced with montane elevation due to the altitudinal decrease of 
temperature which enhances orographic $\mathrm{Hg}$ and cloudwater deposition (Stankwitz et al., 2012; Zhang et al., 2013). However, soil moisture from glacier melting might have been more important for the wetland growth at Tiquimani than at Escalerani due to its lower elevation.

\section{Discussion}

\subsection{Historical reconstruction of mercury deposition with precipitation along the Holocene}

Combining the section from 163 to $96 \mathrm{~cm}$ of the core ET3 with the entire ESC core, we reconstructed changes in $\mathrm{Hg}$ deposition over the last 13.5 millennia, with the exception of a hiatus between 9400 and 7560 cal. BP. Both Escalerani and Tiquimani records allow identifying at least six main episodes of $\mathrm{Hg}$ rises that can be attributed to wet episodes coinciding in part with reported wet phases along the Holocene (Fig. 4).

The first episode is encountered during the Early Holocene period between 9700 and 9300 cal. BP with a slight increase in $\mathrm{Hg}$ concentration $\left(16 \pm 7 \mathrm{ng} \mathrm{g}^{-1}\right)$ and $\mathrm{Hg} \mathrm{AR}\left(1.4 \pm 0.9 \mu \mathrm{g} \mathrm{m}^{-2} \mathrm{y}^{-1}\right)$ from the background values $\left(5.4 \pm 1.4 \mathrm{ngg}^{-1}\right.$ and $0.9 \pm 0.2 \mu \mathrm{g} \mathrm{m}^{-2} \mathrm{y}^{-1}$ for mean $[\mathrm{Hg}]$ and $\mathrm{Hg} \mathrm{AR}$ in ET3, respectively) of the preceding dry episodes. This suggests that Escalerani watershed was free of ice and fed by sufficient melt and/or rain water for the development of the peat. This unit is followed by a temporal hiatus (ET3). This first episode ( $\mathrm{Hg}$ rise and hiatus) coincides with the Coipasa events dated between 9500 and $8500 \mathrm{cal}$. BP, a period characterized by a precipitation increase and a substantial rise in temperature and solar radiation in the central Andes (Sylvestre et al., 1999; Thompson et al., 1998).

The following episodes are encountered during the Middle Holocene (i.e., between 7000 and $4000 \mathrm{cal}$. BP) with at least 4 peaks recorded simultaneously in our two records. Surprisingly, these peaks occurred during a period which was reported as a sudden and long lasting warm and dry period in the central Andes as illustrated by a 4\%o increase in $\delta^{18} \mathrm{O}_{\text {ice }}$ values in the Sajama ice core (Fig. 4 - (Thompson et al., 1998)), the retreat of Telata glacier (Fig. 1) from above $4100 \mathrm{~m}$ to an equilibrium line at $4800 \mathrm{~m}$ a.s.l. (Jomelli et al., 2011) and a major drop of Lake Titicaca level (Fig. 4 - (Rowe et al., 2002; Weide et al., 2017)). The first peaks, between $\sim 7000$ and 6000 cal. BP, are encountered during the set-up period of both TK 1-2 and ESC records where the pollen content of these sediments likely represents mixed material released after ice melting and not the original vegetation (Escobar-Torrez et al., 2018; Ledru et al., 2013). At Escalerani, Hg AR rises abruptly up to 10fold the background levels in the ESC core. Then, two peaks in $\mathrm{Hg}$ concentrations and $\mathrm{Hg}$ AR which almost doubled in ESC core $\left(2.6 \pm 1.4 \mu \mathrm{g} \mathrm{m}^{-2} \mathrm{y}^{-1}\right) \quad$ compared to dry episodes $\left(1.4 \pm 0.4 \mu \mathrm{g} \mathrm{m}^{-2} \mathrm{y}^{-1}\right.$ - Fig. 4$)$ are recorded at 5100 and $4300 \mathrm{cal}$. BP, simultaneously in our two records. The oldest peak coincides with rises in the $\mathrm{T} / \mathrm{P}$ index and drops in $\delta^{13} \mathrm{C}$ that are synchronous for the two records (Fig. 3). Although dry conditions were reported on the Altiplano during the mid-Holocene (Baker and Fritz, 2015), this pattern suggests long lasting wet conditions in our study sites that can be attributed to the occurrence of moist niches in the Eastern Cordillera maintained locally by convective precipitation from the Amazon lowlands. Indeed, previous studies suggested that moist conditions have been enabled by glacier melting and water evaporation from the trees in the Amazon Basin lifted to high elevations where the warm saturated air condenses, producing rainfall on the eastern slope of the Andes (Escobar-Torrez et al., 2018; Killeen et al., 2007; Ledru et al., 2013; Wielicki et al., 2002). During the beginning of this mid-Holocene period, the observed delay of $\sim 800$ yrs. in $\mathrm{Hg}$ peaks and set-up period between our two records is likely inferred to their respective altitude and geographic position making both erosional and glacier dynamics disconnected (see Section 3.3). The end of the middle Holocene is characterized by the peak found at $\sim 4300 \mathrm{cal}$. BP synchronous for the two records. In opposition to TK 1-2, this $\mathrm{Hg}$ peak in ESC (at $50 \mathrm{~cm}-$
Fig. 3) shows an inverse trend with a drop in T/P index and a rise in $\delta^{13} \mathrm{C}$. However, this peak coincides with the major detrital event observed in core ET3 (Fig. 2) and the water level rise in both the small and large basins of Lake Titicaca (Fig. 4), which rather supports the occurrence of a wet event at $\sim 4300 \mathrm{cal}$. BP. This is consistent with other paleoclimate records who demonstrated that through different proxies at numerous sites throughout tropical Africa and South America, the end of the middle-Holocene period underwent a relatively rapid climate shift recorded around 5000-4000 cal. BP although the reasons for such an abrupt shift are only partly understood and still under debate (Grosjean et al., 2003; Marchant and Hooghiemstra, 2004; McGee et al., 2013; Schneider et al., 2014; Talbot and Laerdal, 2000).

During the late Holocene, three major $\mathrm{Hg}$ peaks are recorded in ESC between (i) 3500 and 2600 cal. BP, (ii) 1700 and $1050 \mathrm{cal} \mathrm{BP}$ and (iii) 600 and 200 cal. BP, simultaneously with T/P rises and drops in $\delta^{13} \mathrm{C}$ highlighting long-lasting wet events. Although $\mathrm{Hg}$ concentration peaks exhibit large amplitudes (up to $240 \mathrm{ng} \mathrm{g}^{-1}$ ), $\mathrm{Hg}$ ARs in ESC core for the first wet episode $\left(1.5 \pm 0.2 \mu \mathrm{g} \mathrm{m}^{-2} \mathrm{y}^{-1}\right)$ remain close to the background values of dry episodes $\left(0.9 \pm 0.1 \mu \mathrm{g} \mathrm{m}^{-2} \mathrm{y}^{-1}\right.$ - Fig. 3) resulting from a decrease in sedimentation rates that lowers the calculated $\mathrm{Hg}$ ARs. This event of decrease in peat growth at ESC during a period of enhanced cloud convection activity (i.e., high Yungas pollens frequency) has already been attributed to a reduction in the bog water table (i.e., less meltwater) where a decrease in Poaceae frequency (which do not survive when disconnected from the groundwater) was found synchronous to an increase in Plantago frequency and $\mathrm{T} / \mathrm{P}$ index (Escobar-Torrez et al., 2018).

In opposition, the second event shows a rise in $\mathrm{Hg} \mathrm{AR}$ $\left(2.3 \pm 0.9 \mu \mathrm{g} \mathrm{m}^{-2} \mathrm{y}^{-1}\right)$ while the next one remains lower $\left(1.7 \pm 0.3 \mu \mathrm{g} \mathrm{m}^{-2} \mathrm{y}^{-1}\right)$. This entire period is characterized by a return to warmer and wetter conditions that led the Lake Titicaca to reach nearly its actual level coinciding with the rise of Andean civilizations. These three wet episodes coincide with positive shifts in $\delta^{18} \mathrm{O}_{\text {ice }}$ in the Sajama ice core and rises in Lake Titicaca level (Fig. 4). In the Tiquimani record, the period from $2000 \mathrm{cal}$. BP to present is characterized by a gradual rise in $\mathrm{Hg}$ concentrations and $\mathrm{T} / \mathrm{P}$ (Fig. 3) suggesting lower amplitude in dry vs. wet intensity or a gradual enhancement of convective moisture and $\mathrm{Hg}$ deposition.

The last 2000 years of our record correspond to the rise of preColumbian and colonial mining and metallurgy, where silver was extracted by smelting or amalgamation with $\mathrm{Hg}$, in centers like Potosi, Huancavelica or Puno (Nriagu, 1994; Schultze, 2008; Schultze et al., 2016). Major anthropogenic $\mathrm{Hg}$ emissions are dated of the colonial mining after $\sim 350$ yrs BP and were recorded at Laguna Negrilla (Peru Fig. 4) and Laguna Lobato (Potosi, Bolivia) with higher $\mathrm{Hg}$ AR than for the industrial period (Cooke et al., 2009, 2011). Although the nearest and earlier pre-Columbian silver mining activities are reported on the shores of Lake Titicaca between 2000 and 500 cal. BP, our records did not record such emissions (Fig. 4). Hence, it is probable that the remote eastern position of our study sites in the Cordillera protected them from the western influence of mining regions as they are mainly fed by moisture incoming from the Amazon region.

For the recent period of our record (i.e., last $\sim 200 \mathrm{yrs}$ ), a clear disconnection between $\mathrm{Hg}$ and pollen contents is found with a large rise of 10 to 60 times higher $\mathrm{Hg} \mathrm{AR}$ (i.e., up to $130 \mu \mathrm{g} \mathrm{m}^{-2} \mathrm{y}^{-1}$ ) than the mean fluxes of our record $\left(2.5 \pm 1.9 \mu \mathrm{g} \mathrm{m}^{-2} \mathrm{y}^{-1}\right)$. This period is known to be humid as Lake Titicaca reached its actual level (Weide et al., 2017) which explains the high $\mathrm{Hg}$ depositions in our records. The discrepancy observed between $\mathrm{Hg}$ and pollen content is easily explained by both the industrial revolution and the rise of goldmining activities in the Amazon basin, which are the most important worldwide sources of $\mathrm{Hg}$ ever recorded (Grimaldi et al., 2015; Telmer and Veiga, 2009). Thus, in this modern period, anthropogenic Hg emission, overwhelm natural background emissions making the proxy irrelevant.

The comparison of our profiles with the 12,000 years $\mathrm{Hg}$ record of Laguna Yanacocha (Beal et al., 2014), located $\sim 350 \mathrm{~km}$ North-West 
from Escalerani strikingly depicts similar patterns peaking synchronously with discussed wet episodes (Fig. 4), at least during the early and late Holocene. In their study, the authors could not show evidence of relationship between $\mathrm{Hg}$ and their precipitation proxies. Consequently, they suggested that early mining was the main driver of $\mathrm{Hg} \mathrm{AR}$ fluctuations during the Middle and Late Holocene. However, according to the similitude between the two $\mathrm{Hg}$ profiles together with similar geographic positions (fringe between Amazonia and the Cordillera), we suggest that the Yanacocha record is very likely driven by an atmospheric signature of the Amazon. Such hypothesis is consistent with the absence of the colonial $\mathrm{Hg}$ peak in Yanacocha, as well as in other records located in southern Peru where atmospheric circulation likely prevented the dispersion of $\mathrm{Hg}$ in nearby down-wind regions (Beal et al., 2013).

Apart from the anthropogenic sources, the main natural $\mathrm{Hg}$ source that could have affected our records is volcanism (Pyle and Mather, 2003; Ribeiro Guevara et al., 2010; Roos-Barraclough et al., 2002b). Major volcanic eruptions have been reported for the last 4000 years (Volcanic Explosivity Index of $\geq 4$ in the Andean Cordillera Volcanic Zone) including 4 major eruptions of the Yucamane, El Misti, Ubinas and Huaynaputina volcanoes (Siebert and Simkin, 2013) all located in the western side of the Andes. In the Sajama ice core, major peaks of dust particle concentration associated with increased volcanic activities (Fig. 4) were also recorded between 3000 and 1000 cal. BP (Thompson et al., 1998). However, such short-lived ( $\sim 100$ years for peat, 1-10 years for ice) eruptions may have been diluted in our records since no synchronous $\mathrm{Hg}$ peaks with reported eruptions are found during both wet and dry episodes except potentially a small peak synchronous with the Yucamane eruption dated at 3500 cal. BP.

\subsection{Implications for paleoclimatic reconstructions}

Climate change throughout the Holocene has deeply affected landscapes and water resources in the Andes. The inter-annual variability of the South American Summer Monsoon (SASM), which brings moisture to the Altiplano, is notably forced by the El Niño Southern Oscillation (ENSO - (Grimm, 2003, 2004; Paegle and Mo, 2002)) but also by the Pacific Decadal Oscillation, the tropical Atlantic variability, cold air incursions from the mid-latitudes and by the Atlantic Multidecadal Oscillation (AMO) (Baker et al., 2005; Chiessi et al., 2009; Marengo, 2004; Vuille, 1999; Zhou and Lau, 2001). So far, the explanation of climatically significant variations on paleoclimate time scales in the SASM region are not well constrained. Some authors attributed to ENSO the regular climate anomalies associated with changes in SST in the Pacific Ocean, causing intense changes in the expression of the wet season in the Andes at decadal scale (Garreaud et al., 2003). In opposition, other authors concluded that ENSO variance for the past 7000 years was slightly different from the modern one, suggesting the absence of any influence for long-term (e.g., multi-decadal to millennial) drought or flood cycles in the SASM region (Baker and Fritz, 2015; Masson-Delmotte et al., 2013).

The resolution of our records (35-100 and 50-250 $\mathrm{yr} \mathrm{cm}^{-1}$ for ESC and TK 1-2, respectively) is not sufficient to allow identifying decadal variability potentially associated with ENSO or Atlantic teleconnection. However, it allows studying the millennial cycles of the SASM in the central Andes region. Thus, we tested the relationships between the North Atlantic climate or the ENSO and precipitation variation on the Altiplano by comparing our $\mathrm{Hg}$ records with the Holocene ice-rafted debris record from the North Atlantic (Bond et al., 2001) and the alkenone-based reconstruction of Eastern Equatorial Pacific SST (Rein et al., 2005). The reasonable correspondence between HSG and Hg records supports the hypothesized role of North Atlantic SST in forcing Altiplano summer precipitation at least for the late Holocene period (Fig. 5), confirming the observations of Baker et al. (2009, 2005) for other records in the Andean Altiplano. In opposition, the absence of a coherent pattern with positive SST anomalies in the eastern equatorial
Pacific (Kanner et al., 2013) suggests that ENSO is unlikely a major driver of precipitation in the eastern central Andes (Schneider et al., 2018). Hence, as observed in lakes of the Altiplano, precipitation fluctuations in the eastern Andean cordillera occurred in phase with North Atlantic cold climate events during the late Holocene (Baker and Fritz, 2015; Baker et al., 2009, 2005; Bond et al., 2001; Vuille et al., 2012). The resulting SASM intensification related to a southward displacement of the Intertropical Convergence Zone (ITCZ) likely acted as the main driver for summer moisture (Haug et al., 2001; Seillès et al., 2016). Over the middle Holocene, precipitations are unlikely to be simply related to the same mechanism. During this arid phase, moisture was likely due to orography which depends on the presence or density of forest in the low altitudes of the Amazon flanks and on the temperature gradients between the Amazon and the Andean summits that are likely regulated by the glaciers volumes (Cook, 2009; Killeen et al., 2007; Ledru et al., 2013; Urrutia and Vuille, 2009). Additionally, other mechanisms for moisture transport to the Andes were proposed through the southwestern Amazon or through extratropical cold air incursions propagating northward east of the Andes toward low latitudes which triggered precipitation along their leading front (Apaéstegui et al., 2018; Hurley et al., 2015).

As discussed in Section 4.1, the general pattern of our two records is consistent with the Yanacocha Hg AR record at least for the early and late Holocene. However, several discrepancies are found in amplitude or synchronicity between this study and our data (S.I. 4) which likely result in the spatiotemporal variability of the SASM intensity between the two sites distant of $\sim 3^{\circ}$ of latitude (Fig. 1) or in the existence of specific local or regional moist niches (e.g. size and/or distance of the nearest glacier).

\section{Conclusions}

The good consistency between temporal fluctuations of $\mathrm{Hg}$ deposition and those of $\delta^{13} \mathrm{C}$ and Amazonian pollens deposited by cloud dripping shows that, during the Holocene at the fringe between the Amazon and the Andes, $\mathrm{Hg}$ is mainly deposited by orographic precipitations from the Amazonian region.

Our records confirm that while a sharp regional decrease in moisture during the middle Holocene arid phase is observed in Andean Altiplano lake records, high-elevation peatlands of the eastern cordillera remained moist owing to upslope convective activity from lowland Amazonian rainforests and glacier melting. In the following late Holocene period, both $\mathrm{Hg}$ and precipitation fluctuations occurred in phase with North Atlantic cold climate events. At that time, the related southward displacement of the Intertropical Convergence Zone (ITCZ) likely acted as the main driver for moisture in the central Andes. During the pre-industrial epoch, the down-wind position of our records likely prevented the deposition of $\mathrm{Hg}$ from regional mining activities in the Andes. Finally, during the last past 200 years, $\mathrm{Hg}$ emissions from both the global industrialization and the recent rise of goldmining in Amazonia overwhelm natural background emissions making the proxy irrelevant.

Further studies of peat and lake sediment archives along a 15 to $25^{\circ}$ South gradient of the Cordillera will allow discriminating local moisture niches from regional events and evaluating the intensity and duration of the main moisture events and their hydrological response at the regional scale.

\section{Acknowledgments}

This work has been supported by a grant from Labex OSUG@2020 (Investissements d'avenir - ANR10 LABX56) and IRD (Institut de Recherche pour le Developpement) project PaleoBol.

All radiocarbon dating were performed in the frame of the agreement between IRD and LMC14 (CEA-CNRS-IRD-IRSN-MCC). We thank Ilham Bentaleb for providing the TOC measurements of Tiquimani and 


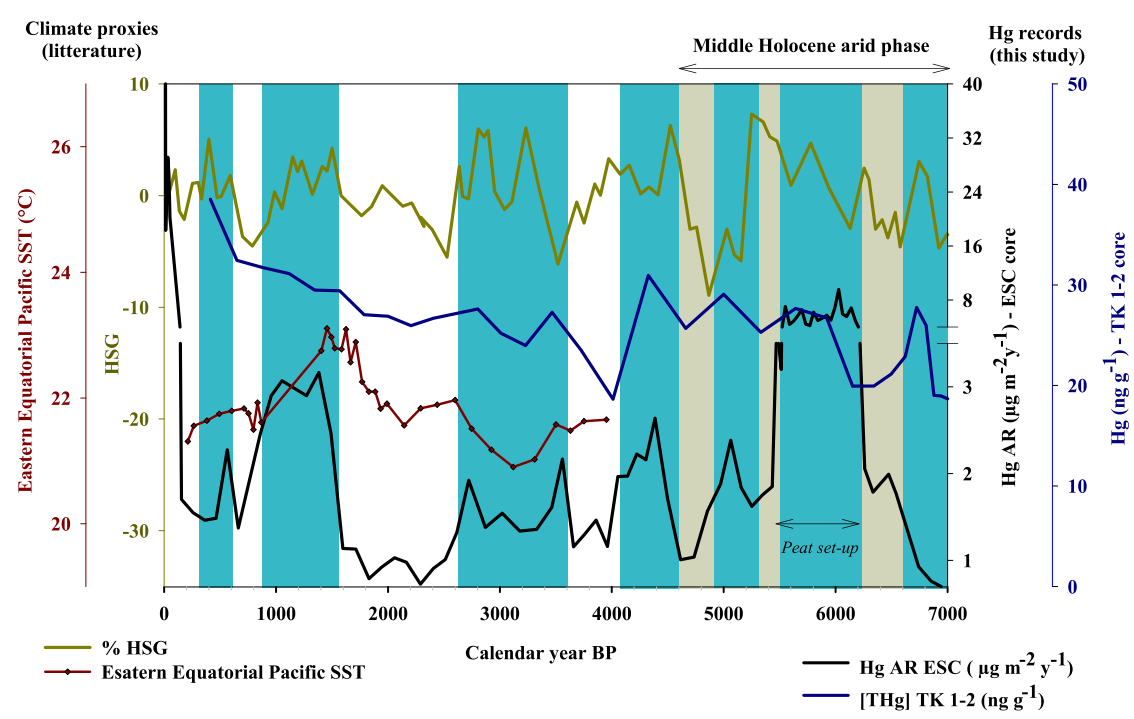

Fig. 5. Comparison of the $\mathrm{Hg}$ accumulation rates of the Escalerani record (black line), $\mathrm{Hg}$ concentration of the Tiquimani record (blue line) with the percentage haematite stained grain (HSG) record (dark yellow line) from VM29-191 (Bond et al., 2001) and reconstruction of Eastern Equatorial Pacific SST (Red line - Rein et al., 2005). Blue bands correspond to wet episodes identified from pollen analyses and the brown background band covers the middle-Holocene arid phase. (For interpretation of the references to colour in this figure legend, the reader is referred to the web version of this article.)

Vincent Perrot for proofreading and his constructive comments. Finally, we greatly thank the two anonymous reviewers who greatly improved the manuscript with their thoughtful comments.

\section{Appendix A. Supplementary data}

Supplementary data to this article can be found online at https:// doi.org/10.1016/j.palaeo.2018.09.023.

\section{References}

Allan, M., Le Roux, G., Sonke, J.E., Piotrowska, N., Streel, M., Fagel, N., 2013. Reconstructing historical atmospheric mercury deposition in Western Europe using: Misten peat bog cores, Belgium. Sci. Total Environ. 442, 290-301.

Amos, H.M., Sonke, J.E., Obrist, D., Robins, N., Hagan, N., Horowitz, H.M., Mason, R.P., Witt, M., Hedgecock, I.M., Corbitt, E.S., 2015. Observational and modeling constraints on global anthropogenic enrichment of mercury. Environ. Sci. Technol. 49, 4036-4047.

Andersson, A., 1979. Mercury in soils. In: Nriagu, J.O. (Ed.), The Biogeochemistry of Mercury in the Environment. Elsevier, pp. 80-111.

Apaéstegui, J., Cruz, F.W., Vuille, M., Fohlmeister, J., Espinoza, J.C., Sifeddine, A., Strikis, N., Guyot, J.L., Ventura, R., Cheng, H., Edwards, R.L., 2018. Precipitation changes over the eastern Bolivian Andes inferred from speleothem $\left(\delta^{18} \mathrm{O}\right)$ records for the last 1400 years. Earth Planet. Sci. Lett. 494, 124-134.

Baker, P.A., Fritz, S.C., 2015. Nature and causes of Quaternary climate variation of tropical South America. Quat. Sci. Rev. 124, 31-47.

Baker, P.A., Fritz, S.C., Garland, J., Ekdahl, E., 2005. Holocene hydrologic variation at Lake Titicaca, Bolivia/Peru, and its relationship to North Atlantic climate variation. J. Quat. Sci. 20, 655-662.

Baker, P.A., Fritz, S.C., Burns, S.J., Ekdahl, E., Rigsby, C.A., 2009. The Nature and Origin of Decadal to Millennial Scale Climate Variability in The southern Tropics of South America: the Holocene Record of Lago Umayo, Peru, Past Climate Variability in South America and Surrounding Regions. Springer, pp. 301-322.

Barbosa, J.A., Cordeiro, R.C., Silva, E.V., Turcq, B., Gomes, P.R.S., Santos, G.M., Sifedinne, A., Albuquerque, A.L.S., Lacerda, L.D., Hausladen, P.A., 2004. ${ }^{14}$ C-AMS as a tool for the investigation of mercury deposition at a remote Amazon location. Nucl. Instrum. Methods Phys. Res., Sect. B Beam Interactions Mater. Atoms 223, 528-534.

Beal, S.A., Jackson, B.P., Kelly, M.A., Stroup, J.S., Landis, J.D., 2013. Effects of historical and modern mining on mercury deposition in Southeastern Peru. Environ. Sci. Technol. 47, 12715-12720.

Beal, S.A., Kelly, M.A., Stroup, J.S., Jackson, B.P., Lowell, T.V., Tapia, P.M., 2014. Natural and anthropogenic variations in atmospheric mercury deposition during the Holocene near Quelccaya Ice Cap, Peru. Glob. Biogeochem. Cycles 28, 437-450.

Biester, H., Kilian, R., Franzen, C., Woda, C., Mangini, A., Schöler, H.F., 2002. Elevated mercury accumulation in a peat bog of the Magellanic Moorlands, Chile $\left(53^{\circ} \mathrm{S}\right)$ - an anthropogenic signal from the Southern Hemisphere. Earth Planet. Sci. Lett. 201, 609-620.

Biester, H., Bindler, R., Martinez-Cortizas, A., Engstrom, D.R., 2007. Modeling the past atmospheric deposition of mercury using natural archives. Environ. Sci. Technol. 41, 4851-4860.

Bindler, R., 2006. Mired in the past - looking to the future: geochemistry of peat and the analysis of past environmental changes. Glob. Planet. Chang. 53, 209-221.

Blaauw, M., 2010. Methods and code for 'classical' age-modelling of radiocarbon sequences. Quat. Geochronol. 5, 512-518.
Bond, G., Kromer, B., Beer, J., Muscheler, R., Evans, M.N., Showers, W., Hoffmann, S., Lotti-Bond, R., Hajdas, I., Bonani, G., 2001. Persistent solar influence on North Atlantic climate during the Holocene. Science 294, 2130-2136.

Braconnot, P., Otto-Bliesner, B., Harrison, S., Joussaume, S., Peterchmitt, J.Y., Abe-Ouchi, A., Crucifix, M., Driesschaert, E., Fichefet, T., Hewitt, C.D., 2007a. Results of PMIP2 coupled simulations of the Mid-Holocene and Last Glacial Maximum-Part 1: experiments and large-scale features. Clim. Past 3, 261-277.

Braconnot, P., Otto-Bliesner, B., Harrison, S., Joussaume, S., Peterchmitt, J.Y., Abe-Ouchi, A., Crucifix, M., Driesschaert, E., Fichefet, T., Hewitt, C.D., 2007b. Results of PMIP2 coupled simulations of the Mid-Holocene and Last Glacial Maximum-Part 2: feedbacks with emphasis on the location of the ITCZ and mid-and high latitudes heat budget. Clim. Past 3, 279-296.

Chiessi, C.M., Mulitza, S., Pätzold, J., Wefer, G., Marengo, J., 2009. Possible impact of the Atlantic Multidecadal Oscillation on the South American summer monsoon. Geophys. Res. Lett. 36.

Cook, K.H., 2009. South American Climate Variability and Change: Remote and Regional Forcing Processes, Past Climate Variability in South America and Surrounding Regions. Springer, pp. 193-212.

Cooke, C.A., Balcom, P.H., Biester, H., Wolfe, A.P., 2009. Over three millennia of mercury pollution in the Peruvian Andes. Proc. Natl. Acad. Sci. 106, 8830-8834.

Cooke, C.A., Balcom, P.H., Kerfoot, C., Abbott, M.B., Wolfe, A.P., 2011. Pre-Colombian mercury pollution associated with the smelting of argentiferous ores in the Bolivian Andes. AMBIO: AMBIO J. Hum. Environ. 40, 18-25.

Cooke, C.A., Hintelmann, H., Ague, J.J., Burger, R., Biester, H., Sachs, J.P., Engstrom, D.R., 2013. Use and legacy of mercury in the Andes. Environ. Sci. Technol. 47, 4181-4188.

Demers, J.D., Blum, J.D., Zak, D.R., 2013. Mercury isotopes in a forested ecosystem: Implications for air-surface exchange dynamics and the global mercury cycle. Glob. Biogeochem. Cycles 27, 222-238.

Enrico, M., Roux, G., Marusczak, N., Heimburger, L.-E., Claustres, A., Fu, X., Sun, R. Sonke, J.E., 2016. Atmospheric mercury transfer to peat bogs dominated by gaseous elemental mercury dry deposition. Environ. Sci. Technol. 50, 2405-2412.

Enrico, M., Le Roux, G., Heimbürger, L.-E., Van Beek, P., Souhaut, M., Chmeleff, J. Sonke, J.E., 2017. Holocene atmospheric mercury levels reconstructed from peat bog mercury stable isotopes. Environ. Sci. Technol. 51, 5899-5906.

Escobar-Torrez, K., Ortuño, T., Bentaleb, I., Ledru, M.-P., 2018. Cloud dynamic contribution to high-elevation peatland growth during the Holocene (Escalerani, Central Andes, Bolivia). In: The Holocene. 28. pp. 1334-1344.

Farquhar, G.D., Sharkey, T.D., 1982. Stomatal conductance and photosynthesis. Annu. Rev. Plant Physiol. 33, 317-345.

Fritz, S.C., Baker, P.A., Tapia, P., Garland, J., 2006. Spatial and temporal variation in cores from Lake Titicaca, Bolivia/Peru during the last 13,000 yrs. Quat. Int. 158, 23-29.

Fitzgerald, W., Mason, R., 1994. The global mercury cycle: oceanic and anthropogenic aspects. In: W., B. (Ed.), Global and Regional Mercury Cycles: Sources, Fluxes and Mass Balances, pp. 85-108.

Fitzgerald, W.F., Lamborg, C.H., Turekian, H.D., Holland, K.K., 2014. 11.4 - Geochemistry of Mercury in the Environment, Treatise on Geochemistry, Second Edition. Elsevier, Oxford, pp. 91-129.

Garreaud, R., Vuille, M., Clement, A.C., 2003. The climate of the Altiplano: observed current conditions and mechanisms of past changes. Palaeogeogr. Palaeoclimatol Palaeoecol. 194, 5-22.

Givelet, N., Roos-Barraclough, F., Shotyk, W., 2003. Predominant anthropogenic sources and rates of atmospheric mercury accumulation in southern Ontario recorded by peat cores from three bogs: comparison with natural "background" values (past 8000 years). J. Environ. Monit. 5, 935-949.

Graydon, J.A., St. Louis, V.L., Lindberg, S.E., Hintelmann, H., Krabbenhoft, D.P., 2006. 
Investigation of mercury exchange between forest canopy vegetation and the atmosphere using a new dynamic chamber. Environ. Sci. Technol. 40, 4680-4688.

Grimaldi, M., Guédron, S., Grimaldi, C., 2015. Impact of gold mining on mercury contamination and soil degradation in Amazonian ecosystems of French Guiana. In: Brearley, F.Q., Thomas, A.D. (Eds.), Land-use Change Impacts on Soil Processes: Tropical and Savannah Ecosystems. CABI, Wallingford, UK, pp. 95-107.

Grimm, A.M., 2003. The El Niño impact on the summer monsoon in Brazil: regional processes versus remote influences. J. Clim. 16, 263-280.

Grimm, A.M., 2004. How do La Niña events disturb the summer monsoon system in Brazil? Clim. Dyn. 22, 123-138.

Grosjean, M., Cartajena, I., Geyh, M.A., Nuñez, L., 2003. From proxy data to paleoclimate interpretation: the mid-Holocene paradox of the Atacama Desert, northern Chile. Palaeogeogr. Palaeoclimatol. Palaeoecol. 194, 247-258.

Guédron, S., Grangeon, S., Lanson, B., Grimaldi, M., 2009. Mercury speciation in a tropical soil association; consequence of gold mining on $\mathrm{Hg}$ distribution in French Guiana. Geoderma 153, 331-346.

Guédron, S., Grangeon, S., Jouravel, G., Charlet, L., Sarret, G., 2013. Atmospheric mercury incorporation in soils of an area impacted by a chlor-alkali plant (Grenoble, France): Contribution of canopy uptake. Sci. Total Environ. 445-446, 356-364.

Guédron, S., Amouroux, D., Sabatier, P., Desplanque, C., Develle, A.-L., Barre, J., Feng, C., Guiter, F., Arnaud, F., Reyss, J.L., Charlet, L., 2016. A hundred year record of industrial and urban development in French Alps combining $\mathrm{Hg}$ accumulation rates and isotope composition in sediment archives from Lake Luitel. Chem. Geol. 431, 10-19.

Guédron, S., Point, D., Acha, D., Bouchet, S., Baya, P.A., Molina, C.I., Tessier, E., Monperrus, M., Flores, M., Fernandez Saavedra, P., Espinoza, M.E., Heredia, C., Rocha, S., Groleau, A., Amice, E., Thebault, J., Alanoca, L., Duwig, C., Uzu, G., Lazzaro, X., Bertrand, A., Bertrand, S., Barbaud, C., Gibon, F.M., Ibanez, C., Zepita, C., Chauvaud, L., Amouroux, D., 2017. Mercury contamination level and speciation inventory in the hydrosystem of Lake Titicaca: current status and future trends. Environ. Pollut. 231, 262-270.

Guédron, S., Amouroux, D., Tessier, E., Grimaldi, C., Barre, J., Berail, S., Perrot, V., Grimaldi, M., 2018. Mercury isotopic fractionation during pedogenesis in a tropical forest soil catena (French Guiana): deciphering the impact of historical goldmining. Environ. Sci. Technol. https://doi.org/10.1021/acs.est.8b02186.

Guentzel, J.L., Landing, W.M., Gill, G.A., Pollman, C.D., 2001. Process influencing rainfall deposition of mercury in Florida. Environ. Sci. Technol. 35, 863-873.

Haug, G.H., Hughen, K.A., Sigman, D.M., Peterson, L.C., Röhl, U., 2001. Southward migration of the intertropical convergence zone through the Holocene. Science 293, 1304-1308.

Hogg, A.G., Hua, Q., Blackwell, P.G., Niu, M., Buck, C.E., Guilderson, T.P., Heaton, T.J., Palmer, J.G., Reimer, P.J., Reimer, R.W., 2013. SHCal13 Southern Hemisphere calibration, 0-50,000 years cal BP. Radiocarbon 55, 1889-1903.

Hua, Q., Barbetti, M., Rakowski, A.Z., 2013. Atmospheric radiocarbon for the period 1950-2010. Radiocarbon 55, 2059-2072.

Hurley, J.V., Vuille, M., Hardy, D.R., Burns, S.J., Thompson, L.G., 2015. Cold air incursions, $\delta^{18} \mathrm{O}$ variability, and monsoon dynamics associated with snow days at Quelccaya Ice Cap, Peru. J. Geophys. Res.-Atmos. 120, 7467-7487.

Jomelli, V., Khodri, M., Favier, V., Brunstein, D., Ledru, M.-P., Wagnon, P., Blard, P.-H., Sicart, J.-E., Braucher, R., Grancher, D., 2011. Irregular tropical glacier retreat over the Holocene epoch driven by progressive warming. Nature 474, 196.

Kanner, L.C., Burns, S.J., Cheng, H., Edwards, R.L., Vuille, M., 2013. High-resolution variability of the South American summer monsoon over the last seven millennia: insights from a speleothem record from the central Peruvian Andes. Quat. Sci. Rev. $75,1-10$.

Killeen, T.J., Douglas, M., Consiglio, T., Jørgensen, P.M., Mejia, J., 2007. Dry spots and wet spots in the Andean hotspot. J. Biogeogr. 34, 1357-1373.

Lacerda, L.D., Ribeiro, M.G., Cordeiro, R.C., Sifeddine, A., Turcq, B., 1999. Atmospheric mercury deposition over Brazil during the past 30,000 years. Ciencia e Cultura 51, 363-371.

Lacerda, L.D., Turcq, B., Sifeddine, A., Cordeiro, R.C., 2017. Mercury accumulation rates in Caço Lake, NE Brazil during the past 20,000 years. J. S. Am. Earth Sci. 77, 42-50.

Lawson, S.T., Scherbatskoy, T.D., Malcolm, E.G., Keeler, G.J., 2003. Cloud water and throughfall deposition of mercury and trace elements in a high elevation spruce-fir forest at Mt. Mansfield, Vermont. J. Environ. Monit. 5, 578-583.

Ledru, M.-P., Jomelli, V., Bremond, L., Ortuño, T., Cruz, P., Bentaleb, I., Sylvestre, F., Kuentz, A., Beck, S., Martin, C., Paillès, C., Subitani, S., 2013. Evidence of moist niches in the Bolivian Andes during the mid-Holocene arid period. The Holocene 23, 1547-1559.

Liebmann, B., Mechoso, C.R., 2011. The south American Monsoon system. In: Chang, C.P., Lau, N.C., Johnson, R.H., Wang, B., Yasunari, T. (Eds.), The Global Monsoon System. World Scientific, pp. 137-157.

Marchant, R., Hooghiemstra, H., 2004. Rapid environmental change in African and South American tropics around 4000 years before present: a review. Earth Sci. Rev. 66, 217-260.

Marengo, J.A., 2004. Interdecadal variability and trends of rainfall across the Amazon basin. Theor. Appl. Climatol. 78, 79-96.

Marsh, E.J., Bruno, M.C., Fritz, S.C., Baker, P., Capriles, J.M., Hastorf, C.A., 2018. IntCal, SHCal, or a mixed curve? Choosing a ${ }^{14} \mathrm{C}$ calibration curve for archaeological and paleoenvironmental records from tropical South America. Radiocarbon 1-16.

Masson-Delmotte, V., Schulz, M., Abe-Ouchi, A., Beer, J., Ganopolski, A., González Rouco, J.F., Jansen, E., Lambeck, K., Luterbacher, J., Naish, T., Osborn, T., Otto-Bliesner, B., Quinn, T., Ramesh, R., Rojas, M., Shao, X., Timmermann, A., 2013. Climate change 2013: the physical science basis. In: Press, C.U. (Ed.), Contribution of Working Group I to the Fifth Assessment Report of the Intergovernmental Panel on Climate Change, Cambridge, pp. 383-464.

McGee, D., Winckler, G., Stuut, J.B.W., Bradtmiller, L.I., 2013. The magnitude, timing and abruptness of changes in North African dust deposition over the last 20,000 yr. Earth Planet. Sci. Lett. 371, 163-176.

Mourguiart, P., Argollo, J., Corre, T., Martin, L., Montenegro, M.E., Sifeddine, A., Wirmann, D., 1997. Changements limnologiques et climatologiques dans le bassin du lac Titicaca (Bolivie), depuis 30000 ans. C. R. Acad. Sci. Ser. IIA Earth Planet. Sci. 325, 139-146.

Moy, C.M., Seltzer, G.O., Rodbell, D.T., Anderson, D.M., 2002. Variability of El Niño/ Southern Oscillation activity at millennial timescales during the Holocene epoch. Nature 420, 162-165.

Nagy, K.L., Manceau, A., Gasper, J.D., Ryan, J.N., Aiken, G.R., 2007. New Mechanisms of Mercury Binding to Peat, AGU Fall Meeting Abstracts. American Geophysical Union.

Nriagu, J.O., 1994. Mercury pollution from the past mining of gold and silver in the Americas. Sci. Total Environ. 149, 167-181.

Ortuño, T., Ledru, M.-P., Cheddadi, R., Kuentz, A., Favier, C., Beck, S., 2011. Modern pollen rain, vegetation and climate in Bolivian ecoregions. Rev. Palaeobot. Palynol. $165,61-74$.

Paegle, J.N., Mo, K.C., 2002. Linkages between summer rainfall variability over South America and sea surface temperature anomalies. J. Clim. 15, 1389-1407.

Pirrone, N., Mason, R., 2009. Mercury Fate and Transport in the Global Atmosphere. Springer, Dordrecht, The Netherlands (DOI 10). (978-970).

Pirrone, N., Cinnirell, S., Feng, X., Finkelman, R.B., Friedli, H.R., Leaner, J., Mason, R., Mukherjee, A.B., Stracher, G., Streets, D.G., Telmer, K., 2009. Global mercury emissions to the atmosphere from natural and anthropogenic sources. In: Pirrone, N., R, a.M. (Eds.), Mercury Fate and Transport in the Global Atmosphere. Springer, pp. 3-50.

Prado, L., Wainer, I., Chiessi, C., Ledru, M.-P., Turcq, B., 2013a. A mid-Holocene climate reconstruction for eastern South America. Clim. Past 9, 2117-2133.

Prado, L.F., Wainer, I., Chiessi, C.M., 2013b. Mid-Holocene PMIP3/CMIP5 model results: intercomparison for the South American monsoon system. The Holocene 23, 1915-1920.

Pyle, D.M., Mather, T.A., 2003. The importance of volcanic emissions for the global atmospheric mercury cycle. Atmos. Environ. 37, 5115-5124.

Rein, B., Lückge, A., Reinhardt, L., Sirocko, F., Wolf, A., Dullo, W.C., 2005. El Niño variability off Peru during the last 20,000 years. Paleoceanography 20.

Ribeiro Guevara, S., Meili, M., Rizzo, A., Daga, R., Arribére, M., 2010. Sediment records of highly variable mercury inputs to mountain lakes in Patagonia during the past millennium. Atmos. Chem. Phys. 10, 3443-3453.

Richter, T.O., der Gaast, Van, 2006. The Avaatech XRF Core Scanner: technical description and applications to NE Atlantic sediments. In: Rothwell, R.G. (Ed.), New Techniques in Sediment Core Analysis. Geological Society, London, pp. 39--50.

Robins, N.A., Hagan, N.A., 2012. Mercury production and use in colonial Andean silver production: emissions and health implications. Environ. Health Perspect. 120, 627.

Roche, M.A., Bourges, J., Cortes, J., Mattos, R., 1992. IV.1. Climatology and hydrology of the Lake Titicaca basin. In: Dejoux, C., Iltis, A. (Eds.), Lake Titicaca - A Synthesis of Limnological Knowledge. Kluwer Academic Publishers, Dordrecht/Boston/London, pp. 63-88.

Rodbell, D.T., Seltzer, G.O., Anderson, D.M., Abbott, M.B., Enfield, D.B., Newman, J.H., 1999. An 15,000-year record of El Niño-driven alluviation in southwestern Ecuador. Science 283, 516-520.

Roos-Barraclough, F., Givelet, N., Martinez-Cortizas, A., Goodsite, M.E., Biester, H., Shotyk, W., 2002a. An analytical protocol for determination of total mercury concentration in solid peat samples. Sci. Total Environ. 292, 129-139.

Roos-Barraclough, F., Martinez-Cortizas, A., Garcia-Rodeja, E., Shotyk, W., 2002b. A 14 500 year record of the accumulation of atmospheric mercury in peat: volcanic signals, anthropogenic influences and a correlation to bromine accumulation. Earth Planet. Sci. Lett. 202, 435-451.

Rowe, H.D., Dunbar, R.B., Mucciarone, D.A., Seltzer, G.O., Baker, P.A., Fritz, S., 2002. Insolation, moisture balance and climate change on the South American Altiplano since the Last Glacial Maximum. Clim. Chang. 52, 175-199.

Rowe, H.D., Guilderson, T.P., Dunbar, R.B., Southon, J.R., Seltzer, G.O., Mucciarone, D.A., Fritz, S.C., Baker, P.A., 2003. Late Quaternary lake-level changes constrained by radiocarbon and stable isotope studies on sediment cores from Lake Titicaca, South America. Glob. Planet. Chang. 38, 273-290.

Santos, G.M., Cordeiro, R.C., Silva Filho, E.V., Turcq, B., Lacerda, L.D., Fifield, L.K., Gomes, P.R.S., Hausladen, P.A., Sifeddine, A., Albuquerque, A.L.S., 2001. Chronology of the atmospheric mercury in Lagoa da Pata basin, Upper Rio Negro region of Brazilian Amazon. Radiocarbon 43, 801-808.

Schneider, T., Bischoff, T., Haug, G.H., 2014. Migrations and dynamics of the intertropical convergence zone. Nature 513, 45-53.

Schneider, T., Hampel, H., Mosquera, P.V., Tylmann, W., Grosjean, M., 2018. Paleo-ENSO revisited: Ecuadorian Lake Pallcacocha does not reveal a conclusive El Niño signal. Glob. Planet. Chang. 168, 54-66.

Schultze, C.A., 2008. The Role of Silver Ore Reduction in Tiwanaku State Expansion into Puno Bay, Peru. ProQuest.

Schultze, C.A., Huff, J.A., Rehren, T., Levine, A.R., 2016. The emergence of complex silver metallurgy in the Americas: a case study from the Lake Titicaca Basin of Southern Peru. Camb. Archaeol. J. 26, 53-64.

Seillès, B., Sanchez Goñi, M.F., Ledru, M.-P., Urrego, D.H., Martinez, P., Hanquiez, V., Schneider, R., 2016. Holocene land-sea climatic links on the equatorial Pacific coast (Bay of Guayaquil, Ecuador). The Holocene 26, 567-577.

Shotyk, W., Goodsite, M.E., Roos-Barraclough, F., Frei, R., Heinemeier, J., Asmund, G., Lohse, C., Hansen, T.S., 2003. Anthropogenic contributions to atmospheric $\mathrm{Hg}, \mathrm{Pb}$ and As accumulation recorded by peat cores from southern Greenland and Denmark dated using the ${ }^{14} \mathrm{C}$ "bomb pulse curve". Geochim. Cosmochim. Acta 67, 3991-4011.

Shotyk, W., Goodsite, M.E., Roos-Barraclough, F., Givelet, N., Le Roux, G., Weiss, D., Cheburkin, A.K., Knudsen, K., Heinemeier, J., van Der Knaap, W.O., 2005. 
Accumulation rates and predominant atmospheric sources of natural and anthropogenic $\mathrm{Hg}$ and $\mathrm{Pb}$ on the Faroe Islands. Geochim. Cosmochim. Acta 69, 1-17.

Siebert, L., Simkin, T., 2013. Volcanoes of the World: An Illustrated Catalog of Holocene Volcanoes and Their Eruptions.

Stankwitz, C., Kaste, J.M., Friedland, A.J., 2012. Threshold increases in soil lead and mercury from tropospheric deposition across an elevational gradient. Environ. Sci. Technol. 46, 8061-8068.

Sylvestre, F., Servant, M., Servant-Vildary, S., Causse, C., Fournier, M., Ybert, J.-P., 1999. Lake-level chronology on the Southern Bolivian Altiplano (18-23 S) during lateglacial time and the early Holocene. Quat. Res. 51, 54-66.

Talbot, M.R., Laerdal, T., 2000. The Late Pleistocene-Holocene palaeolimnology of Lake Victoria, East Africa, based upon elemental and isotopic analyses of sedimentary organic matter. J. Paleolimnol. 23, 141-164.

Telmer, K., Veiga, M.M., 2009. World Emissions of mercury from artisanal and small scale gold mining. In: Pirrone, N., Mason, R. (Eds.), Mercury Fate and Transport in the Global Atmosphere Emissions, Measurements and Models. Springer, pp. 131-172.

Thevenon, F., Guédron, S., Chiaradia, M., Loizeau, J.-L., Poté, J., 2011. (Pre-) historic changes in natural and anthropogenic heavy metals deposition inferred from two contrasting Swiss Alpine lakes. Quat. Sci. Rev. 30, 224-233.

Thompson, L.G., Davis, M.E., Mosley-Thompson, E., Sowers, T.A., Henderson, K.A., Zagorodnov, V.S., Lin, P.N., Mikhalenko, V.N., Campen, R.K., Bolzan, J.F., 1998. A 25,000-year tropical climate history from Bolivian ice cores. Science 282,
1858-1864.

Urrutia, R.o., Vuille, M., 2009. Climate change projections for the tropical Andes using a regional climate model: temperature and precipitation simulations for the end of the 21st century. J. Geophys. Res.-Atmos. 114.

Vuille, M., 1999. Atmospheric Circulation Over the Bolivian Altiplano During dry and wet Periods and Extreme Phases of the Southern Oscillation.

Vuille, M., Burns, S.J., Taylor, B.L., Cruz, F.W., Bird, B.W., Abbott, M.B., Kanner, L.C., Cheng, H., Novello, V.F., 2012. A review of the South American monsoon history as recorded in stable isotopic proxies over the past two millennia. Clim. Past 8, 1309.

Wang, G., Han, J., Liu, D., 2003. The carbon isotope composition of $\mathrm{C}^{3}$ herbaceous plants in loess area of northern China. Sci. China Ser. D Earth Sci. 46, 1069-1076.

Weide, D.M., Fritz, S.C., Hastorf, C.A., Bruno, M.C., Baker, P.A., Guédron, S., Salenbien, W., 2017. A $\sim 6000$ yr diatom record of mid-to late Holocene fluctuations in the level of Lago Winaymarca, Lake Titicaca (Peru/Bolivia). Quat. Res. 1-14.

Wielicki, B.A., Wong, T., Allan, R.P., Slingo, A., Kiehl, J.T., Soden, B.J., Gordon, C.T., Miller, A.J., Yang, S.-K., Randall, D.A., 2002. Evidence for large decadal variability in the tropical mean radiative energy budget. Science 295, 841-844.

Zhang, H., Yin, R.-s., Feng, X.-b., Sommar, J., Anderson, C.W.N., Sapkota, A., Fu, X.-w., Larssen, T.r., 2013. Atmospheric mercury inputs in montane soils increase with elevation: evidence from mercury isotope signatures. Sci. Rep. 3.

Zhou, J., Lau, K.M., 2001. Principal modes of interannual and decadal variability of summer rainfall over South America. Int. J. Climatol. 21, 1623-1644. 